\title{
Pemberdayaan Kader Dalam Manajemen KIPI Pada Vaksinasi Covid-19 Di Wilayah Kerja Puskesmas Bandarharjo
}

\author{
Rani Tiyas Budiyanti ${ }^{1}$, Nurhasmadiar Nandini ${ }^{2 *}$, Sutopo Patria Jati ${ }^{3}$, Septo Pawelas Arso ${ }^{4}$, \\ Eka Yunila Fatmasari ${ }^{5}$ \\ 1,2,3,4,5 Fakultas Kesehatan Masyarakat, Universitas Diponegoro, Semarang, Indonesia \\ ${ }^{1}$ ranitiyas@lecturer.undip.ac.id , ${ }^{2}$ nurhasmadiar.nandini@live.undip.ac.id , ${ }^{3}$ spjati@gmail.com, ${ }^{4}$ septo.arso@gmail.com, \\ ${ }^{5}$ ekafatmasari@gmail.com
}

\begin{abstract}
Indonesia targeting that at least $70 \%$ of the population vaccinated and formed the herd immunity. However, there are several challenges in reaching that target, such as the anti-vaccine movements, disinformation or hoaxes, fear of the Adverse Event Following Immunization (AEFI), and fear of needles. Based on the preliminary study, the area of Bandarharjo Public Health Centre was in the lowest $3^{\text {rd }}$ place related to the COVID-19 vaccination coverage in Semarang. This was due to lack of education to the community regarding the vaccination, the high resistance to vaccination due to concerns about AEFI, and so on. Health cadres are one of the main actors in the supporting the health programs in PHC, therefore the role of health cadres need to be optimized in education and management of AEFI related to COVID-19 vaccination. This community service program was carried out offline in 30 health cadres in the working area of Bandarharjo PHC. The activity began with a pre-test, continued with the presentation of the topic, discussion session, and ends with post-test. The results of the pre-test and post-test showed that there was an increase in the knowledge of cadres between before the presentation and after the presentation session. Health cadres also received booklets containing general information about COVID-18 vaccination and also related to AEFI. Booklets given to cadres not only to increase their knowledge but also can be used to educate the community. Hopefully, with the increase in knowledge and understanding of cadres, the community will be easily get the right information. The health cadres commitment to educate the community regarding COVID-19 vaccination also hoped to increase the community knowledge related to the vaccination and also the willingness of community to receive the COVID-19 vaccination, especially in the working area of Bandarharjo PHC, Semarang City, Central Java Province.
\end{abstract}

Keywords : health cadres, AEFI, COVID-19 vaccination

\begin{abstract}
Abstrak
Indonesia mentargetkan dapat melakukan vaksinasi kepada minimal 70\% penduduk untuk membentuk kekebalan kelompok. Meskipun demikian, terdapat beberapa tantangan seperti gerakan antivaksin, disinformasi atau hoax, ketakutan akan kemananan dan kejadian ikutan pasca imunisasi, dan ketakutan akan jarum suntik. Berdasarkan studi pendahuluan, cakupan vaksinasi COVID-19 di wilayah Puskesmas Bandarharjo menduduki peringkat 3 terbawah di Kota Semarang. Hal ini disebabkan karena kurangnya edukasi masyarakat terkait vaksinasi, tingginya penolakan vaksinasi karena kekhawatiran terjadinya KIPI, (Kejadian Ikutan Pasca Imunisasi) dan lain sebagainya. Kader kesehatan merupakan salah satu ujung tombak dalam suksesnya program kesehatan di puskesmas, oleh karena itu peran kader kesehatan perlu dioptimalkan dalam edukasi serta manajemen KIPI terkait vaksinasi COVID-19. Kegiatan pengabdian ini dilakukan secara luring kepada 30 orang kader di wilayah kerja Puskesmas Bandarharjo. Kegiatan diawali dengan pre-test, dilanjutkan dengan pemberian materi dan diskusi tanya jawab, serta diakhiri dengan post-test. Hasil pre-test dan post-test menunjukkan bahwa terdapat peningkatan pengetahuan kader antara sebelum diberikan edukasi dan setelah diberikan edukasi. Pada pengabdian ini, kader kesehatan juga mendapatkan booklet yang berisi informasi umum seputar vaksinasi COVID-19 dan juga informasi mengenai KIPI. Booklet yang diberikan kepada kader selain dapat membantu kader menambah pengetahuan juga dapat digunakan sebagai media edukasi atau penyuluhan kepada masyarakat umum. Diharapkan dengan adanya peningkatan pengetahuan dan pemahaman kader, masyarakat akan lebih mudah menerima informasi yang tepat. Dengan didukung peningkatan komitmen kader kesehatan untuk memberikan edukasi kepada masyarakat
\end{abstract}


terkait vaksinasi COVID-19, diharapkan akan terjadi peningkatan pengetahuan masyarakat dan juga kesediaan masyarakat untuk menerima vaksinasi COVID-19 khususnya di wilayah kerja Puskesmas Bandarharjo, Kota Semarang, Provinsi Jawa Tengah.

Kata Kunci: kader kesehatan, KIPI, vaksinasi COVID-19

*Penulis Korespondensi : (Nurhasmadiar Nandini)

\section{PENDAHULUAN}

Pandemi Coronavirus Disease 2019 (COVID-19) telah menjangkiti berbagai belahan dunia. Penyakit yang disebabkan oleh SARS-Cov-2 ini pertama kali ditemukan di Wuhan pada Desember 2019. Jumlah kasusnya semakin meningkat dari waktu ke waktu, sehingga pada bulan Maret 2019, World Health Organization menetapkan bahwa COVID-19 termasuk dalam Public Health Emergency (World Health Organization, 2020).

Terhitung hingga tanggal 18 Februari 2021 jumlah angka positif COVID-19 di dunia mencapai 109.594.835 kasus sedangkan di Indonesia jumlah kasus positif mencapai 1.262.585 (Satuan Tugas Penanganan COVID19, 2021). Berbagai cara mulai diterapkan untuk mencegah laju penularan penyakit COVID-19. Selain penerapan protokol kesehatan, langkah preventif lain yang diterapkan adalah dengan pembentukan kekebalan komunitas (herd immunity) melalui vaksinasi (World Health Organization, 2021). Langkah ini ditempuh untuk mengurangi angka morbiditas dan mortalitas penduduk terkait COVID-19.

Seiring dengan peningkatan kasus yang terus menerus, serta kemungkinan bahwa virus COVID-19 tidak bisa $100 \%$ dihilangkan, mulai muncul wacana untuk hidup berdampingan dengan virus COVID-19. Karena itu untuk mengurangi angkat morbiditas dan mortalitas penduduk, beberapa autoritas kesehatan kemudian berlomba-lomba untuk menciptakan vaksinasi. Terbilang pada tahun 2020 telah muncul berbagai vaksin yang telah lolos uji klinis fase 2 dan mendapat Emergency Authority dalam penggunaannya sehingga siap untul disebarluaskan dan digunakan (World Health Organization, 2021).

Pada bulan Januari 2021, dilakukan vaksinasi pertama COVID-19 di Indonesia dengan menggunakan vaksin SinoVac selama dua kali dosis pemberian. Vaksinasi tersebut diawali oleh presiden dan diprioritaskan kepada tenaga Kesehatan (Kementerian Kesehatan Republik Indonesia, 2021). Pada rencana ke depan, Indonesia mentargetkan dapat melakukan vaksinasi kepada minimal $70 \%$ penduduk untuk membentuk kekebalan kelompok. Meskipun demikian, terdapat beberapa tantangan dalam penerapan program tersebut seperti gerakan antivaksin, disinformasi atau hoax, ketakutan akan kemananan dan kejadian ikutan pasca imunisasi, dan ketakutan akan jarum suntik.

Sebagai upaya meningkatkan cakupan vaksinasi, dibutuhkan kerjasama dari berbagai sektor. Pemerintah berperan dalam menyusun kebijakan dan menyediakan sumber daya yang diperlukan, namun juga diperlukan peran serta stakeholder lain dan masyarakat agar pemberian vaksinasi dapat berjalan lancar dan mempercepat tercapainya target cakupan imunisasi (Dewi, 2021). Untuk menerapkan kebijakan terkait vaksinasi COVID-19, seharusnya dilakukan upaya sosialisasi yang persuasif kepada masyarakat. Hal ini dapat dilakukan misalnya melalui tokoh masyarakat atau yang lain untuk membantu pemerintah mengajak masyarakat agar bersedia berpartisipasi dalam vaksinasi COVID-19 (Gandryani and Hadi, 2021).

Informasi yang simpang siur terutama terkait keamanan vaksin dan kejadian ikutan pasca imunisasi memerlukan manajemen dan penanganan yang serius demi menyukseskan program vaksinasi yang dilakukan. Informasi mengenai vaksinasi COVID-19 termasuk mengenai Kejadian Ikutan Pasca Imunisasi (KIPI) yang tidak tepat merupakan salah satu penyebab masyarakat ragu-ragu untuk mendapatkan vaksin (Sukmana et al., 2021).

Kader kesehatan merupakan salah satu sumber informasi kesehatan di masyarakat yang dapat membantu meluruskan informasi yang beredar di masyarakat terkait vaksinasi COVID-19 (Wilianarti and Wulandari, 2021). Kader kesehatan merupakan salah satu ujung tombak dalam suksesnya program kesehatan di puskesmas, oleh karena itu peran kader kesehatan perlu dioptimalkan dalam manajemen KIPI terkait vaksinasi COVID-19. 
Berdasarkan studi pendahuluan, cakupan vaksinasi COVID-19 di wilayah Puskesmas Bandarharjo menduduki peringkat 3 terbawah di Kota Semarang. Hal ini disebabkan berbagai faktor, antara lain kurangnya edukasi masyarakat terkait vaksinasi, tingginya penolakan vaksinasi karena kekhawatiran terjadinya KIPI, dan lain sebagainya. Karena itu, sebagai salah satu upaya membantu peningkatan cakupan vaksinasi COVID-19 di wilayah kerja Puskesmas Bandarharjo Kota Semarang, dilakukan pengabdian masyarakat kepada perwakilan kader kesehatan di wilayah kerja Puskesmas Bandarharjo.

\section{METODE}

Kegiatan pengabdian masyarakat dilaksanakan pada 12 Juni 2021 di Puskesmas Bandarharjo. Kegiatan pengabdian ini dilakukan secara luring kepada 30 orang kader di wilayah kerja Puskesmas Bandarharjo. Kegiatan diawali dengan pre-test, dilanjutkan dengan pemberian materi dan diskusi tanya jawab, serta diakhiri dengan post-test. Pre-test dan post-test yang diberikan terdiri dari 10 pertanyaan sederhana terkait informasi dasar mengenai vaksinasi COVID-19 dan KIPI vaksinasi COVID-19. Selain itu kader kesehatan juga mendapatkan buku modul yang dapat digunakan ketika melakukan edukasi kepada masyarakat.

Karena kegiatan dilakukan pada masa pandemi, maka pelaksanaan kegiatan dilakukan dengan menerapkan protokol kesehatan. Kegiatan dilaksanakan dengan membatasi jumlah peserta menjadi separuh dari kapasitas ruangan, menyediakan hand sanitizer, mengatur posisi tempat duduk agar berjarak, serta memeriksa suhu peserta sebelum memasuki ruangan. Selain itu, durasi kegiatan juga dibatasi agar peserta tidak terlalu lama berkumpul di dalam satu ruangan tertutup.

\section{HASIL DAN PEMBAHASAN}

Puskesmas Bandarharjo terletak di Kecamatan Semarang Utara dan membina 4 kelurahan yaitu Kelurahan Bandarharjo, Tanjungmas, Kuningan dan Dadapsari. Puskesmas Bandarharjo memiliki sekitar 200 orang kader kesehatan yang berperan aktif dalam berbagai program kesehatan di masyarakat.

Peserta kegiatan adalah kader kesehatan di Puskesmas Bandarharjo sebanyak 30 orang dengan rentang usia antara 36 sampai dengan 64 tahun. Sebagian besar kader yang berpartisipasi pada kegiatan ini adalah kader berpengalaman. Hanya sebagian kecil kader yang baru menjadi kader kesehatan dalam kurun waktu 1 tahun terakhir. Sedangkan peserta lainnya telah menjadi kader selama lebih dari 1 tahun atau bahkan 20 tahun.

Untuk mengetahui tingkat pengetahuan peserta, dilakukan pre-test sebelum pemberian materi dan posttest setelah pemberian materi. Test ini berisi 10 pernyataan sederhana mengenai informasi umum terkait vaksinasi COVID-19 dan KIPI dan peserta diminta menjawab apakah pernyataan tersebut benar, salah, atau tidak tahu. Pernyataan dalam pre-test dan post-test yang diberikan serta jawaban yang diharapkan, yaitu:

1. Vaksinasi COVID-19 dapat menurunkan risiko kematian akibat COVID-19 (Benar)

2. Orang yang sudah mendapatkan vaksinasi COVID19 pasti tidak akan terkena COVID-19 (Salah)

3. Bengkak pada bekas tempat suntikan vaksin adalah salah satu bentuk KIPI (Benar)

4. Semua orang yang mendapatkan vaksinasi pasti mengalami KIPI (Salah)

5. Jika mengalami KIPI, cukup dibiarkan saja dan tidak perlu dilaporkan (Salah)

6. Masyarakat yang khawatir dengan adanya KIPI tidak perlu mendapatkan vaksinasi COVID-19 (Salah)

7. Reaksi KIPI dibedakan menjadi reaksi ringan dan reaksi berat (Benar)

8. Edukasi terkait KIPI bukan peran kader kesehatan (Salah)

9. Peran kader kesehatan dibutuhkan untuk menangkal berita hoax yang menyebar di masyarakat (Benar)

10. Kader kesehatan perlu berperan aktif untuk mengajak masyarakat berpartisipasi dalam vaksinasi COVID19 (Benar)

Setelah peserta mengisi pre-test dan post-test, hasil kemudian dinilai dan dikelompokkan menjadi 2 kategori, yaitu kategori pengetahuan kurang dan pengetahuan baik. Pengelompokkan ini dilakukan untuk memperlihatkan 
perubahan pengetahuan kader sebelum pemberian materi dan sesudah pemberian materi.

Tabel 1. Hasil Pre-Test dan Post-Test pada Peserta Pengabdian Masyarakat di Puskesmas Bandarharjo

\begin{tabular}{|l|r|r|r|r|}
\hline \multirow{2}{*}{ Kategori } & \multicolumn{2}{|c|}{ Pre-Test } & \multicolumn{2}{c|}{ Post-Test } \\
\cline { 2 - 5 } & $\mathbf{n}$ & $\boldsymbol{\%}$ & $\mathbf{n}$ & \multicolumn{1}{c|}{$\%$} \\
\hline Kurang & 14 & 46,7 & 7 & 23,3 \\
\hline Baik & 16 & 53,3 & 23 & 76,7 \\
\hline Total & 30 & 100 & 30 & 100 \\
\hline \multicolumn{2}{r|}{ Hasil pre-test dan post-test pada tabel 1 }
\end{tabular}

menunjukkan bahwa terdapat peningkatan pengetahuan kader antara sebelum diberikan edukasi dan setelah diberikan edukasi. Hal ini dibuktikan dengan berkurangnya peserta yang termasuk dalam kategori kurang sebanyak 46,7\% menjadi $23,3 \%$ atau sebanyak 7 orang. Selain itu juga terdapat peningkatan pada peserta yang menunjukkan hasil pengetahuan baik, dari 53,3\% menjadi $76,7 \%$.

Pertanyaan pada pre-test dengan jawaban salah yang tertinggi adalah pertanyaan terkait apakah KIPI pasi dialami semua orang yang mendapatkan vaksinasi. Sebanyak 33,3\% kader menjawab tidak tepat dan $16,7 \%$ kader menjawab tidak tahu. Karena itu pada proses penyampaian materi dan diskusi, kader diberikan pemahaman bahwa KIPI tidak selalu dialami semua orang. Setiap orang akan menunjukkan reaksi yang berbeda. Selain itu juga dijelaskan kepada kader terkait jenis KIPI yang mungkin dapat dialami masyarakat setelah mendapatkan vaksinasi COVID-19.

Pertanyaan lainnya yang juga perlu dilakukan penekanan adalah terkait peran kader dalam melakukan edukasi terkait KIPI vaksinasi COVID-19. Sebanyak $30 \%$ menjawab tidak tepat, dan $10 \%$ kader menjawab tidak tahu. Kader merasa edukasi terkait KIPI ke masyarakat bukan merupakan peran dari kader kesehatan. Padahal, peran kader kesehatan sebagai yang paling dekat dengan masyarakat umum sangat penting dalam memberikan edukasi tersebut. Masyarakat umumnya lebih mudah mendapatkan informasi yang tepat melalui kader kesehatan yang ada di sekitar tempat tinggalnya. Karena itu dibutuhkan pemahaman yang baik dari kader serta komitmen kader untuk melakukan edukasi kepada masyarakat sekitarnya.
Selama proses diskusi tanya jawab, kader juga menyampaikan kesulitan yang selama ini dirasakan ketika melakukan penyuluhan kepada masyarakat terkait vaksinasi COVID-19 yang sebagian besar disebabkan karena banyaknya informasi tidak tepat yang beredar di media sosial. Karena itu kader berharap memiliki pedoman yang berisi informasi yang tepat yang dapat digunakan untuk menangkal informasi hoax di masyarakat.

Salah satu keluhan lain yang disampaikan kader ketika melakukan penyuluhan kepada masyarakat adalah masyarakat yang khawatir akan mengalami sakit setelah vaksinasi, dan masyarakat yang merasa bahwa walaupun sudah vaksinasi COVID-19 tetap ada kemungkinan terjangkit COVID-19. Karena itu pada kegiatan ini, kader diberikan pemahaman mengenai KIPI, alur pelaporan, dan bagaimana menyampaikan kepada masyarakat bahwa reaksi tersebut adalah reaksi normal dan akan reda dalam beberapa hari. Selain itu kader juga diberikan penjelasan mengapa orang yang sudah mendapatkan vaksinasi COVID-19 tetap dapat terjangkit COVID-19. Kader juga diberikan pemahaman bahwa walaupun telah mendapatkan vaksin COVID-19, masyarakat tetap harus menerapkan protokol kesehatan.

Pada pengabdian ini, selain pemberian materi secara langsung, kader kesehatan juga mendapatkan booklet yang berisi informasi umum seputar vaksinasi COVID-19 dan juga informasi mengenai KIPI. Booklet yang diberikan kepada kader selain dapat membantu kader menambah pengetahuan juga dapat digunakan sebagai media edukasi atau penyuluhan kepada masyarakat umum. Isi dari booklet berbentuk tanya jawab dan juga disajikan dengan kalimat yang sederhana untuk memudahkan kader dan masyarakat memahami isi dari booklet.

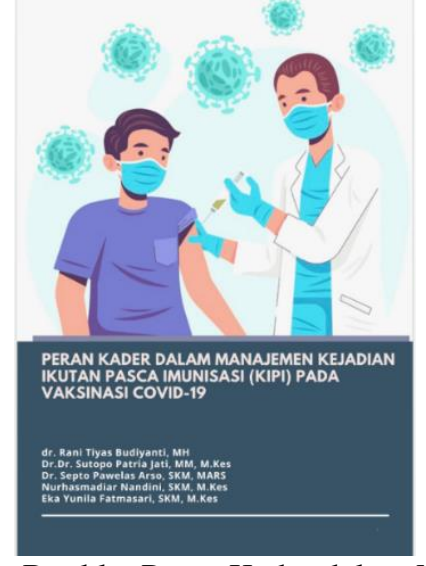

Gambar 1. Booklet Peran Kader dalam Manajemen KIPI pada Vaksinasi COVID-19 
Booklet yang diberikan kepada kader kesehatan memuat informasi antara lain:

a. Vaksinasi COVID-19

b. Pentingnya vaksinasi COVID-19

c. Kejadian Ikutan Pasca Imunisasi (KIPI)

d. Pencatatan dan Pelaporan KIPI

e. Jenis KIPI

f. Peran kader dalam manajemen KIPI

g. Alur pelaporan dan pelacakan KIPI

Pemberian edukasi kepada kader adalah salah satu bentuk upaya mengatasi krisis komunikasi di tingkat masyarakat. Krisis komunikasi publik di masa pandemi ini terjadi mulai di level negara hinggal level masyarakat. Salah satu penyebab utamanya adalah penyebaran informasi yang tidak terkontrol, khususnya informasi yang tidak tepat. Diharapkan dengan adanya penyuluhan oleh kader kepada masyarakat dapat meminimalisir tersebarnya informasi tidak tepat di masyarakat serta meningkatkan kepatuhan masyarakat untuk mematuhi himbauan atau kebijakan pemerintah (Dewi, 2021).

Selain itu, diharapkan dengan adanya peningkatan pengetahuan dan pemahaman kader, masyarakat akan lebih mudah menerima informasi yang tepat. Dengan didukung peningkatan komitmen kader kesehatan untuk memberikan edukasi kepada masyarakat terkait vaksinasi COVID-19, diharapkan akan terjadi peningkatan pengetahuan masyarakat dan juga kesiapan masyarakat untuk menerima vaksinasi COVID-19 khususnya di wilayah kerja Puskesmas Bandarharjo. Sesuai dengan penelitian sebelumnya di Kota Surabaya, terdapat pengaruh antara pengetahuan masyarakat terhadap kesediaan masyarakat untuk mendapatkan vaksinasi COVID-19 (Febriyanti, Choliq and Mukti, 2021).

\section{KESIMPULAN}

Kegiatan pengabdian masyarakat ini dilakukan untuk membantu kader mendapatkan informasi yang tepat mengenai KIPI vaksinasi COVID-19. Informasi ini diharapkan dapat disebarluaskan ke masyarakat umum sehingga dapat membantu meningkatkan keyakinan masyarakat untuk mendapatkan vaksinasi COVID-19 serta meningkatkan cakupan vaksinasi COVID-19 khususnya di wilayah Puskesmas Bandarharjo, Kota
Semarang. Hasil Pre-test dan Post-test menunjukkan terdapat peningkatan pengetahuan pada kader kesehatan peserta kegiatan sejak sebelum mendapatkan edukasi dan setelah mendapatkan edukasi. Seluruh kader yang menjadi peserta kegiatan mendapatkan booklet yang dapat digunakan sebagai sumber informasi dan juga media edukasi kepada masyarakat.

\section{UCAPAN TERIMA KASIH}

Penulis mengucapkan terima kasih kepada Fakultas Kesehatan Masyarakat Universitas Diponegoro sebagai sumber pendanaan kegiatan. Penulis juga menyampaikan terima kasih kepada Puskesmas Bandarhajo Kota Semarang sebagai lokasi kegiatan pengabdian masyarakat, serta seluruh kader Kesehatan di wilayah kerja Puskesmas Bandarharjo Kota Semarang yang telah berpartisipasi pada kegiatan pengabdian masyarakat ini.

\section{DAFTAR PUSTAKA}

Dewi, R. D. C. (2021) 'Literatur Review: Dinamika Komunikasi Kesehatan di Masa Pandemi dan Pasca Vaksin COVID-19', LINIMASA: Jurnal Ilmu Komunikasi, 4(2), pp. 206-213.

doi: http://dx.doi.org/10.23969/linimasa.v4i2.4220.

Febriyanti, N., Choliq, M. I. and Mukti, A. W. (2021) 'Hubungan Tingkat Pengetahuan dan Kesediaan Vaksinasi Covid-19 Pada Warga Kelurahan Dukuh Menanggal Kota Surabaya', Seminar Nasional Hasil Riset dan Pengabdian, pp. 36-42.

Gandryani, F. and Hadi, F. (2021) 'Pelaksanaan Vaksinasi Covid-19 Di Indonesia: Hak Atau Kewajiban Warga Negara', Jurnal Rechts Vinding: Media Pembinaan Hukum Nasional, 10(1), pp. 23-41. Available at: https://rechtsvinding.bphn.go.id/ejournal/index.php/jrv/arti cle/viewFile/622/259.

Kementerian Kesehatan Republik Indonesia (2021) Program Vaksinasi COVID-19 Mulai Dilakukan, Presiden Orang Pertama Penerima Suntikan Vaksin COVID-19. Available at: http://p2p.kemkes.go.id/program-vaksinasi-covid-19mulai-dilakukan-presiden-orang-pertama-penerimasuntikan-vaksin-covid-19/ (Accessed: 30 June 2021).

Satuan Tugas Penanganan COVID-19 (2021) Peta Sebaran. Available at: https://covid19.go.id/peta-sebaran (Accessed: 19 February 2021). 
Sukmana, R. A. et al. (2021) 'Implementasi Strategi Komunikasi Kesehatan dalam Meyakinkan Masyarakat untuk Pelaksanaan Vaksinasi COVID-19 di Kabupaten Barito Kuala', Jurnal Sains Sosio Humaniora, 5(1), pp. 409-419.

Wilianarti, P. F. and Wulandari, Y. (2021) 'Optimalisasi Peran Kader Menggunakan Peer Group Education dalam Meningkatkan Cakupan Vaksinasi COVID-19', SELAPARANG: Jurnal Pengabdian Masyarakat Berkemajuan, 4(3), pp. 872-878. Available at: http://journal.ummat.ac.id/index.php/jpmb/article/view/54 26/3187.

World Health Organization (2020) Coronavirus. Available at: https://www.who.int/health-topics/coronavirus\#tab=tab_1.

World Health Organization (2021) COVID-19 advice for the public: Getting vaccinated. Available at: https://www.who.int/emergencies/diseases/novel-

coronavirus-2019/covid-19-vaccines/advice (Accessed: 15 July 2021) 